\title{
VERIFICATION OF ASSESSMENT SCALES OF THE SENSORY ENRICHED ENVIRONMENT ECERS-R AND SSTEW OR IMPLEMENTATION IN UKRAINE
}

\author{
Kateryna Kruty \\ Vinnytsia Mykhailo Kotsiubynskyi State Pedagogical University, Ukraine \\ Oksana Holiuk \\ Vinnytsia Mykhailo Kotsiubynskyi State Pedagogical University, Ukraine \\ Nataliia Rodiuk \\ Vinnytsia Mykhailo Kotsiubynskyi State Pedagogical University, Ukraine \\ Oksana Popovych \\ Mukachevo State University,Ukraine \\ Larysa Zdanevych \\ Khmelnytskyi Humanitarian-Pedagogical Academy, Ukraine \\ Olha Bilska \\ Vinnytsia Mykhailo Kotsiubynskyi State Pedagogical University, Ukraine \\ Natalia Pakhalchuk \\ Vinnytsia Mykhailo Kotsiubynskyi State Pedagogical University, Ukraine
}

\begin{abstract}
The quality of education in general and preschool education in particular remains relevant both in the light of current reforms in the educational sphere of Ukraine and in the international context. Scientists pay attention to solving the problem of organizing comfortable environment, in particular the lack of internal space for each child. So far, the problems of teaching educators of preschooleducation establishments for the assessment of a high-quality sensory enriched environment have not been fully resolved.

The purpose of the article is to determinate the effective quality scales of preschool education, to verify the most acceptable scales for assessment of the sensory enriched environment, to compare analysis of the obtained experimental data. During the research we used the following methods: observation, analysis, interviews, mathematical statistics, scales ECERS-R (Early Childhood Environment Rating Scale-Revised) and SSTEW (Sustained Shared Thinking and Emotional Well-being).

The assessment of the condition of the sensory enriched environment was conducted by the 3rd year undergraduate students studying at the educational program «Preschool Education» at Vinnytsia Mykhailo Kotsiubynskyi State Pedagogical University, Mukachevo State University, Khmelnytskyi Humanitarian-Pedagogical Academy. At the stage of experimental
\end{abstract}


activity, 21 experts, 30 educators were involved, 15 environments in preschool establishments were evaluated.

The analysis of the main features of the external and internal sensory enriched environment, which was carried out on the basis of the proposed parameters of the ECERS and SSTEW scales, allows us to determine the features that set out the possibility of further enrichment of this environment. The authors propose to focus on the enrichment of the environment as a special means of integrating the accumulated pedagogical experience into a holistic pedagogical system, as well as the complexity of the child's development situation, which is taken into account by adults.

Keywords: assessment scales, sensory enriched environment, ECERS-R, SSTEW, preschool education establishments, quality of preschool education.

\section{Introduction}

The quality of preschool education is a topical issue not only of modern reforms in the educational sphere of Ukraine, but also in the international context. The report "Improving the quality of preschool education and child care in Ukraine" by Jan Peeters, Doctor of Education, University of Ghent (Belgium), with the financial support of the United Nations Children's Fund (UNICEF), has considered $75.4 \%$ of children from 3 to 6 years $(84.5 \%$ - in urban settlements and only $57.8 \%$ - in rural areas) attend preschool educational establishments (Peeters, 2019). This index is slightly higher than similar one in other countries for example as in neighboring Georgia (69.5\%), but much lower than in the EU (95\% of children from 4 to 6 years) (Kryterii yakosti doshkilnoi osvity [KYDO], 2019, 8). Some problems of preschool educators training to examination of high quality sensory enriched environment have not been solved yet.

There are contradictions between:

- the numerous experimental studies in the field of creating an environment for young children and the low level of their implementation in the practice of preschool education;

- the high level of validity of the theory and its insufficient implementation in the content of professional and pedagogical training of future early childhood educators and practicing preschool teachers;

- $\quad$ the need to ensure the quality of the sensory enriched environment and the lack of specially trained specialists in the relevant field;

- the need to consolidate and integrate the efforts of preschools and other social institutions to create a sensory enriched environment for the development of young children and the lack of theoretical and methodological support for pedagogical partnerships in quality assurance of preschool education (Krutii, Kit, Holiuk, \& Stakhova, 2020). 
The purpose of the research is determining the effectiveness of preschool education quality scales for implementation in the educational field of Ukraine, verification of the most acceptable scale for use in order to examine the sensory enriched environment, a comparative analysis of the obtained experimental data.

Research methods include observation, analysis, interviewing, mathematical data processing, ECERS-R and SSTEW scales.

\section{The Theoretical Background}

The attention to solving the problem of organizing a comfortable environment, in particular the lack of internal space for each child is paid by doctors, designers, architects, as well as psychologists and teachers. They define the quality of the educational process as a set of interactions and experiences that the child receives in the kindergarten classroom, being in its social, sensory and physical environment (Diskowski, 2006). At the end of the 20th century some researches noticed that the structure of the process of interaction between a teacher and a child in most institutions has to be considered unsatisfactory. In particular, there were minimum game situations in the environment registered in the collective interaction, which takes about $5 \%$ of the observed time. It turned out that children have less pair than group interactions with teachers. Only 5\% of the time is used to encourage children to play outdoors without performing special exercises, while $13 \%$ of spare time is filled with play activities planned by the teacher.

Assessment of the quality of preschool education (set of conditions) is a controlled process. It should not be formed spontaneously. It's difficult to assess the quality of preschool education because any child educational results cannot be chosen as an external assessment of the quality of preschool education of the particular preschool educational establishment (hereinafter - PEE), in contrast to primary school institutions). Thus, in 2014, the European Commission established a working group to develop recommendations for defining the quality criteria to preschool education (Key Data on Early Childhood Education and Care in Europe, 2014). Emphasizing the complexity of the concept of quality of preschool education, the working group outlined the following main criteria: the quality of the structure, the quality of the process and the quality of the result. Let's characterize them.

Quality of structure. This criterion includes the peculiarities of accreditation and licensing programs; correspondence of the number of staff to the number of children in PEE; ensuring equal access to quality education for all children, sanitary and hygienic norms, etc.

Quality of the process includes practices used at preschool institutions, the part of game techniques at the educational programs; cooperation between 
educators and parents of children; interaction between educators and children, as well as between the children themselves; integrated approach to education, care and training of children.

Quality of results includes benefits for children (emotional, cognitive, physical development, development of social skills and preparation for further learning and adult life), benefits for families, as for local communities and society as a whole (KYDO, 2019, 10).

Unfortunately, there are few effective tools for a comprehensive assessment of the quality of preschool education as in the Ukrainian pedagogy of early and preschool childhood, as in the theory and practice of management. However, in the practice of foreign colleagues such tools have been developed and they are relevant and valid.

The assessment scale of the educational environment Early Childhood Environment Rating Scale-Revised (ECERS-R), which is translated into various languages and standardized in many countries, is the most well known in the United States, Canada, Asia and Europe. This tool was developed in 1980 at the USA. It was modified in 2005 (Harms, Clifford, \& Crye, 2005), and in 2010 an additional scale was created together with British experts (Sylva K., SirajBlatchford E., Taggart B.). That one emphasizes the preparing children for mastering learning skills (ECERS-E) (Sylva, Siraj-Blatchford, \& Taggart, 2010). In particular, it is used by the NAEYC in conducting accreditations, as it stated in the introduction to the description of the scale (Harms et al., 2005). ECERS includes scales of observations that allow to assess one specific educational group of institutions (Anikeich, 2017; Harms et al., 2005). Researches show that ECERS is a tool flexible enough to assess different educational conditions (Montessori pedagogy, Waldorf program, Step-by-step, etc.).

We have analyzed another scale for assessing sustainable shared thinking and emotional well-being SSTEW (Sustained Shared Thinking and Emotional Well-being) - a new tool for studying and evaluating the work of preschool educational establishments (Siradzh, Kingston, \& Melhish, 2020). The scale covers 14 criteria that have clear indicators that reflect the trends of quality development in the practice of kindergartens. The indicators (subscale) include:

Subscale 1. Development of trust, confidence and independence.

Subscale 2. Social and emotional well-being.

Subscale 3. Support and development of speech and communication skills.

Subscale 4. Support the learning process and the development of critical thinking.

Subscale 5. Assessment of the learning process and speech development.

The first two subscales assess the quality of conditions for ensuring the independence of children and their social and emotional well-being in the adult environment. 
In the international educational field, there are some scales that assess the conditions of a child's development, such as:

1. The scales for assessing the educational environment.

Early Childhood Environment Rating Scale-Revised (ECERS-R). The evaluation procedure is based primarily on observation and recording the results of it to the evaluation protocols with explanations of why that or another evaluation is chosen for each criterion. There are observation scales in ECERS that allow to assess the educational environment of a particular class of kindergarten. The environment in preschool education plays a significant developmental role. The experts from "Reggio Emilia" consider "environment as a third teacher".

2. The scale of practices assessment in education of young children (Assessment of Practices in Early Elementary Classrooms (APEEC)).

3. The Child-Adult Interaction Scale (CIS). This scale is often used to assess pedagogical impact at home or in childcare centers.

4. The scale of observations of children's interaction in the classroom (Classroom Assessment Scoring System (CLASS)). This scale is of particular interest to professionals because the sphere of interaction between child and adult is the most problematic point of any education due to historical cultural reasons.

5. The scale of observations after language and literacy development at preschool age (ELLCO: Early Language and Literacy Classroom Observation). This scale is designed specifically to assess the conditions of a child's development in an educational institution.

It is important to note that each of the scales is the result not only of testing, but also of serious and large-scale research, which allow us to see the relationship between the results obtained by PEE and various effects and relationships.

Thus, the ECERS-R educational environment assessment scale is the most well-known, translated into different languages and standardized in many countries one. As for the SSTEW scale, it is almost unknown in the Ukrainian educational environment (Krutii \& Popovych, 2020a; Siradzh et al., 2020).

Many approaches define the concept of quality of preschool education, tools and procedures for its evaluation at the level of preschool education. However, the scales that focus on two objects of quality assessment of educational activities, such as educational environment and educational outcomes of children (Krutii, 2019) prevail among them. The analysis of the scale points shows that the assessment of the quality of the environment, conducted with the help of ECERS and SSTEW, shows researchers:

- $\quad$ if the environment creates conditions for the emotional well-being of the child; 
- $\quad$ if children are active in the learning process;

- $\quad$ if the conditions to stimulate children's curiosity and learning are created;

- $\quad$ if there is a balance between actions initiated by adults and children themselves;

- $\quad$ if the environment promotes the development of creative and critical thinking of children.

\section{Methodology, Organization and Results of the Research}

The quality of the sensory enriched environment was identified with standardized interviews and surveys of leaders, teaching staff of the PEE, document analysis and examinations then and there. Relationships with families were revealed through written survey of parents. The quality of the educational process was designated through 3-4-hour observation of specially trained specialists in the kindergarten groups and by additional interview with the group educator.

The examination of the sensory enriched environment included the scaling of

- $\quad$ the level of comfort and safety;

- $\quad$ ensuring the development of holistic sensory perception;

- $\quad$ providing independent individual children's activities (the ability to use the subject for its intended purpose);

- providing opportunities for research and training (elements of experimentation);

- $\quad$ functionality of the subject environment (variability, transformability);

- $\quad$ approachability for children;

- emotional saturation of the environment (brightness, sound signals, mobile);

- $\quad$ age matching.

The assessment of the content of the sensory enriched environment in terms of the development of subject activity was carried out according to the following characteristics that were common to ECERS as to SSTEW scale:

- $\quad$ a variety of forms of objects;

- $\quad$ reproduction of color of objects;

- $\quad$ sound transmission of objects (for auditory perception);

- $\quad$ objects of advanced nature;

- $\quad$ replacement items (game replacements for real things);

- $\quad$ subject safety;

- $\quad$ kinesthetic modality (tactility, movement, touch, smell). 
The assessment of the sensory enriched environment was carried out by the 3rd year undergraduate students studying in the educational program "Preschool Education" at Vinnytsia Mykhailo Kotsiubynskyi State Pedagogical University, Mukachevo State University, Khmelnytsky Humanitarian and Pedagogical Academy. We initiative the research and guided it. 21 experts and 30 educators were involved during the experimental activity. 15 environments were evaluated, which were unified into groups called "Shchedryk", "Kotyhoroshko", "Barvinok" for the convenience of processing the protocols.

During the training the future educators (experts) for pedagogical practice in the groups of young children, a number of consultations were held on working with the ECERS and SSTEW scales. It was emphasized that the observation of children should be much careful. The observation shouldn't interrupt the current children activity at the class. The questionnaire gave experts the opportunity to become children for a while and try to perceive the environment from the child's point of view, to take a subjective position in relation to both the child and the educational environment (Demchenko, Kit, Holiuk, \& Rodiuk, 2018).

The experts were offered a questionnaire (author - O. Popovych), which they filled out while being in active practice in the groups of young children (Krutii \& Popovych, 2020b). After processing the questionnaire, the future preschool educators got a consultation how to assess the research results. The features of work in the groups of young children were determined. Preparatory work was carried out using ECERS and SSTEW scales.

In the process of observation, future educators filled out a specially designed assessment protocol. Also there were explanations in the assessment protocols of each indicator so that the expert knew how to qualitatively evaluate this or that criterion, what guidelines to pay attention to, what questions can be asked to the educator for the qualitative assessment of particular criterion. The general assessment of the environment's quality in the groups of young children was formed with filling in the protocols and reflecting the facts in them. Thus, this work precluded formal assessment of the sensory enriched environment and reduced the risk of subjective assessment by the expert (student). The results obtained during the examination were qualitative and convincing, because they pointed to the strengths and weaknesses of the environment's quality of particular class in a particular period of time. In summary, we can say that the ECERS and SSTEW scales are universal and are an effective method of assessing the quality of the environment of kindergarten or any center of child development.

The average valuation for each of the subscales was calculated as the arithmetic mean of the scores obtained for each indicator. The final average valuation on the whole scale is the sum of scores on all indicators of the scale. There are the criteria, levels and indicators that we have developed to teach 
students to assess the sensory enriched environment in the group of young children, in Table 1.

\section{Table 1 Criteria, Levels and Indicators of Sensory Enriched Environment on the ECERS and SSTEW Scales}

\begin{tabular}{|c|c|c|}
\hline & Criteria & Levels and indicators \\
\hline \multirow[t]{3}{*}{1.} & \multirow{3}{*}{$\begin{array}{l}\text { The presence of } \\
\text { centers that provide } \\
\text { play, sensory } \\
\text { cognitive and research } \\
\text { activities of children } \\
\text { (children's } \\
\text { experimentation with } \\
\text { sand, water, and other } \\
\text { materials) }\end{array}$} & $\begin{array}{l}\text { Optimal level (80-100\%). There are at least 5-7 centers } \\
\text { (exercises in practical life, for play, sensory and cognitive } \\
\text { development, learning the native language and speech } \\
\text { development, "mini-laboratory" for experiments, including } \\
\text { sand, water; artistic creativity, reading and relaxation, } \\
\text { designing, privacy) in the classroom. }\end{array}$ \\
\hline & & $\begin{array}{l}\text { Average level (60-79\%). There are } 3-4 \text { centers, which } \\
\text { partially provide play, cognitive, research and creative } \\
\text { activity of all children, experimenting with available } \\
\text { materials in the classroom. There is minor inconsistency } \\
\text { with the educational program. }\end{array}$ \\
\hline & & $\begin{array}{l}\text { Lower than average level (less than } 59 \% \text { ). There is no or } \\
\text { minimal number of centers ( } 2-3 \text { ). They provide game, } \\
\text { cognitive, research and creative activity of all children, } \\
\text { experimenting with available materials poorly. }\end{array}$ \\
\hline \multirow[t]{3}{*}{2.} & \multirow{3}{*}{$\begin{array}{l}\text { The presence of } \\
\text { centers that provide } \\
\text { motor activity (gross } \\
\text { and fine motor skills), } \\
\text { participation at } \\
\text { moving games }\end{array}$} & $\begin{array}{l}\text { Optimal level (80-100\%). There are centers of motor } \\
\text { activity in accordance with the Sanitary Regulations (2016) } \\
\text { for the development of gross motor skills with appropriate } \\
\text { sports and play equipment, sports facilities. }\end{array}$ \\
\hline & & $\begin{array}{l}\text { Average level (60-79\%). There is a center for motor } \\
\text { activity, for the development of gross motor skills, a } \\
\text { minimum set of equipment. }\end{array}$ \\
\hline & & $\begin{array}{l}\text { Lower than average level (less than 59\%). There is limited } \\
\text { environment for physical activity, development of gross } \\
\text { motor skills, insufficient amount of appropriate equipment, } \\
\text { sports facilities. }\end{array}$ \\
\hline \multirow[t]{3}{*}{3.} & \multirow{3}{*}{$\begin{array}{l}\text { Ensuring the } \\
\text { possibility of } \\
\text { manifestations of } \\
\text { young children's } \\
\text { independence in } \\
\text { sensory cognitive } \\
\text { activity }\end{array}$} & $\begin{array}{l}\text { Optimal level (80-100\%). There are materials and items } \\
\text { fully prepared for productive activities, as well as for place } \\
\text { to arrangement the products of children's activity ("child's } \\
\text { voice", "child's footprints"), there are free materials there. }\end{array}$ \\
\hline & & $\begin{array}{l}\text { Average level (60-79\%). There is minimum amount of } \\
\text { materials and items for the activities of children, limited } \\
\text { area for placement of products of creative activities. }\end{array}$ \\
\hline & & $\begin{array}{l}\text { Lower than average level (less than } 59 \% \text { ). There is no or } \\
\text { minimum materials for productive activities of children. }\end{array}$ \\
\hline
\end{tabular}

The following Table 2 shows a variant of verification of the obtained data on the ECERS and SSTEW scales. 
SOCIETY. INTEGRATION. EDUCATION

Proceedings of the International Scientific Conference. Volume II, May $28^{\text {th }}-29^{\text {th }}$, 2021. 756-767

Table 2 Verification of the Obtained Data on the ECERS and SSTEW Scales, in \%

\begin{tabular}{|l|c|c|c|c|c|c|}
\hline \multirow{2}{*}{$\begin{array}{l}\text { Scale name } \\
\text { /Levels }\end{array}$} & \multicolumn{3}{|c|}{ Scale ECERS-R } & \multicolumn{3}{c|}{ Scale SSTEW } \\
\cline { 2 - 7 } & $\begin{array}{c}\text { Optimal } \\
\text { level }\end{array}$ & $\begin{array}{c}\text { Average } \\
\text { level }\end{array}$ & $\begin{array}{c}\text { Lower than } \\
\text { average } \\
\text { level }\end{array}$ & $\begin{array}{c}\text { Optimal } \\
\text { level }\end{array}$ & $\begin{array}{c}\text { Average } \\
\text { level }\end{array}$ & $\begin{array}{c}\text { Lower than } \\
\text { average } \\
\text { level }\end{array}$ \\
\hline Barvinok & 17 & 52 & 31 & 15 & 57 & 28 \\
\hline Kotyhoroshko & 15 & 49 & 36 & 18 & 53 & 29 \\
\hline Shchedryk & 18 & 51 & 31 & 17 & 52 & 31 \\
\hline $\begin{array}{l}\text { Average } \\
\text { indicator }\end{array}$ & $\mathbf{1 6 , 7}$ & $\mathbf{5 0 , 7}$ & $\mathbf{3 2 , 6}$ & $\mathbf{1 6 , 7}$ & $\mathbf{5 4 , 0}$ & $\mathbf{2 9 , 3}$ \\
\hline
\end{tabular}

The analysis of the protocols results made it possible to derive the average indicators at the levels of table 2. Thus, the quality of the sensory enriched environment in the analyzed groups of young children was almost similar. Thus, the quality of the sensory enriched environment in the groups "Barvinok", "Kotyhoroshko" and "Shchedryk" is lower than the average level on the ECERS scale $-32.6 \%$ of protocols, on the SSTEW scale $-29.3 \%$ it is almost the same, but the indicators of the group "Kotyhoroshko" are somewhat differ from others. This difference can be explained by the incorrectness of filling in the protocols by students, so it makes sense to revise the content of the protocols in the future to avoid subjectivism on the part of the expert. The obtained data can be clearly seen with the help of Figure 1.

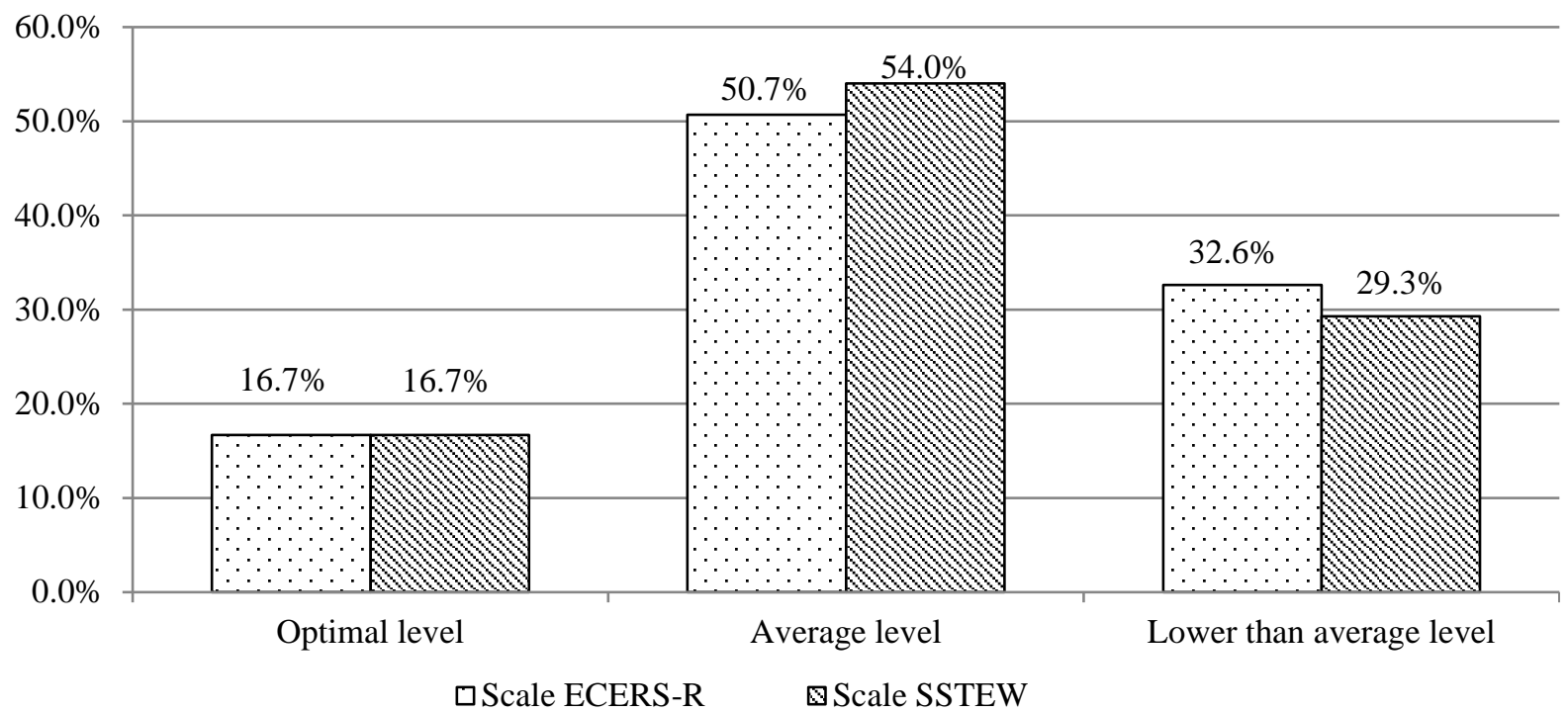

Figure 1 Verification of the Obtained Data on the ECERS and SSTEW Scales on the Quality of the Sensory Enriched Environment in the Groups of Young Children 


\section{Conclusions}

Based on the study, we can draw the following conclusions: the quality of the environment in the studying sample can be characterized as "average". Good results were obtained in terms of indicators related to the equipment of groups of young children with furniture, but they have low scores on the arrangement of centers and focus on children's needs. Expert students did not record that the bedroom was adapted for use during the day. Research has shown that the sensory enriched environment is not intensive and accessible enough to ensure the free spontaneous children's activity. In many ways, this is a reflection of the situation of the tradition of emphasizing frontal classes, the initiative of which belongs entirely to the preschool teachers. In groups of young children there are almost no places for privacy and cozy places. Children's works, results of their recent activity, photos are extremely short used in decoration of group rooms. It can be concluded that the group rooms are adapted for children, but not focused on the development of children's initiative, independence and individuality.

In conclusion, we can say that ECERS and SSTEW are the value of the environment that creates conditions for the emotional well-being of children, as well as the development of children's activity and free will, which allows them to start school actively. This means that the ECERS and SSTEW scales correspond to the ideas of quality preschool education that were formed in the expert educational community before the beginning of the XXI century. Using the ECERS and SSTEW scales, we organized an assessment of the environment of groups of young children. The results of this assessment clearly presented the degree of conformity of an indicator with the requirements of the scales, they provided an opportunity to verify the data, to determine the prospects for further development of the environment, to plan further activities for its enrichment. Note that the format of the SSTEW scale has the same construction as ECERSR, namely: points are evaluated on a seven-point scale, it has division into 5 subscales. However, it should be noted that the concept of the SSTEW scale is more acceptable for the faster implementation it in the educational field of Ukraine.

First of all, it is based on ECERS-R and ECERS-E / ITERS-R, provides research within the environment, clarifies the role of adults in supporting the learning and development of children, takes into account the quality of interaction with children and between them. In our opinion, the teaching staff of preschool education establishments may not be ready to use all subscales without special training. This is relevant to such subscales as: critical thinking, learning assessment, support and promotion of speech and communication. The scales that will be proposed by the state should be used by those who are theoretically trained and know about the peculiarities of creating conditions for 
children's development, and relevant practice. We see such training in conducting systematic learning seminars, workshops and trainings for both heads of preschool education establishments and teachers.

Our findings are consistent with the findings of the Iram Siraj, Denise Kingston and Edward Melhuish study (Siraj, Kingston, \& Melhuish, 2015) on how to promote the SSTEW scale to improve the quality of preschool education.

Therefore, the analysis of the main features of the external and internal sensory enriched environment, which we carried out on the basis of the proposed parameters of the scale ECERS and SSTEW allows us to determine the features that stipulate the possibility of further enrichment of the environment in the conditions of Ukrainian preschool education establishments. Emphasis in the further development of the analyzed problem should be made on enriching the environment as a special means of integrating the accumulated pedagogical experience into a integral pedagogical system, as well as in the complexity of the situation of child development, which is taken into account by adults.

\section{References}

Anikeich, S. (2017). Ispol'zovanie shkal ECERS-R pri ocenke kachestva obrazovatel'noj sredy. Pedagogicheskoe masterstvo (29-31). Moskva: Buki-Vedi. Retrieved from https://moluch.ru/conf/ped/archive/215/12460/

Demchenko, O., Kit, G., Holiuk, O., \& Rodiuk, N. (2018). Development of future teachers' subjectivity in the context of preparation for working with gifted children. Society. Integration. Education, II, 507-519. Retrieved from: http://journals.rta.lv/index.php/ SIE/article/view/3167/3040

Diskowski, D. (2006). Integrierte Bildungssteuerung in der Kindertagesbetreuung. EinAnsatz. KINDER. Retrieved from http://kindergartenpaedagogik.de/1646.html

Key Data on Early Childhood Education and Care in Europe. (2014). Eurydice and Eurostat Report. Luxembourg: Publications Office of the European Union. DOI: https://doi.org/10.2797/75270

Harms, T., Clifford, R., \& Crye, D. (2005). Childhood Environment Rating Scale-Revised Edition. NewYork: TeachersCollegePress.

Krutii, K., \& Popovych, O. (2020a). ECERS-R dlia otsinky sensorno zbahachenoho seredovyshcha hrup rannoho viku. Vykhovatel metodyst doshkilnoho zakladu, 10, 12-16.

Krutii, K. (2019). Empirychne doslidzhennia vilnoi hry dytyny v umovakh zakladu doshkilnoi osvity pid chas provedennia «Dnia bez ihrashok». Humanizatsiia navchalnovykhovnoho protsesu, 1 (93), 26-44. Retrieved from: http://dspace.tnpu.edu.ua/handle/ $123456789 / 12407$

Krutii, K., \& Popovych, O. (2020b). Shcho take sensorno zbahachene seredovyshche. Vykhovatel metodyst doshkilnoho zakladu, 10, 6-10.

Krutii, K., Kit, H., Holiuk, O., \& Stakhova, I. (2020). Osoblyvosti priorytetiv profesiinoho stanovlennia suchasnoho studenta pedahohichnoho zakladu vyshchoi osvity. Naukovi zapysky Vinnytskoho derzhavnoho pedahohichnoho universytetu imeni Mykhaila Kotsiubynskoho. Seriia: pedahohika i psykholohiia, 61, 131-140. 
Kruty et al., 2021. Erification of Assessment Scales of the Sensory Enriched Environment Ecers- $R$ and Sstew or Implementation in Ukraine

Kryterii yakosti doshkilnoi osvity. (2019). Zvit za rezultatamy doslidzhen $v$ mezhakh mizhnarodnoho proektu «Mizhnarodni kryterii yakosti doshkilnykh osvitnikh prohram». Kyiv: Vseukrainskyi fond «Krok za krokom».

Peeters, J. (2019). Improving the quality of ECEC services in Ukraine. Kiev Ukraine: UNICEF Ukraine. Retrieved from: https://www.researchgate.net/publication/ 332112767_Title_Improving_the_quality_of_ECEC_services_in_Ukraine

Siradzh, I., Kingston, D., \& Melhish, E. (2020). Obespechenie ustojchivogo sovmestnogo myshleniya i emocional'nogo blagopoluchiya detej $v$ vozraste ot 2 do 5 let. Moskva: MOZAIKA-SINTEZ.

Siraj, I., Kingston, D., \& Melhuish, E. (2015). Assessing Quality in Early Childhood Education and Care: Sustained Shared Thinking and Emotional Well-being (SSTEW) Scale for 2-5-year-olds Provision. London : Trentham Books Ltd. Retrieved from https://ro.uow.edu.au/sspapers/2278/

Sylva, K., Siraj-Blatchford, E., \& Taggart, B. (2010). Ecers-E: The Four Curricular Subscales Extension to the Early Childhood Environment Rating Scale (Ecers). London: Trentham Books Ltd. 